\title{
Examining the Extended Advertising Value Model: A Case of TikTok Short Video Ads
}

\author{
Bayu Dwinanda ${ }^{1}$ ([) , Fandi Andi Syaripuddin ${ }^{1}$ (i), Hudaifi ${ }^{1}$ ([), Evelyn Hendriana ${ }^{1 *}$ (1)
}

${ }^{1}$ Business Management, Management Department, Binus Business School Master Program, Bina Nusantara University, Jakarta, INDONESIA *Corresponding Author: evelyn.hendriana@binus.ac.id

Citation: Dwinanda, B., Syaripuddin, F. A., Hudaifi, \& Hendriana, E. (2022). Examining the Extended Advertising Value Model: A Case of TikTok Short Video Ads. Mediterranean Journal of Social \& Behavioral Research, 6(2), 35-44. https://doi.org/10.30935/mjosbr/11820

\begin{abstract}
Nowadays, TikTok social media has rapidly developed which creates an opportunity for marketers to grab customers' attention by displaying short video ads. For this reason, knowledge of the factors that can influence customer purchase intentions is needed so that marketing strategies can work effectively. This study aims to investigate the effects of the entertainment, informativeness, credibility, irritation, personalization, and interactivity elements of TikTok short video ads on purchase intention through advertising value and attitude toward advertising. A survey was conducted by collecting response from 486 TikTok active users in Indonesia which later analyzed by using PLS-SEM. The results showed that all elements of video advertising on TikTok, except irritation and informativeness, affected purchase intention through perceived advertising value and attitude toward advertising. Among the significant elements of advertising value, personalization had the greatest positive influence on purchase intention through advertising value and attitude toward advertising on brands that advertised in TikTok.
\end{abstract}

Keywords: advertising value, purchase intention, short video ads, SOR theory, TikTok

Received: 2 Nov. $2021 \bullet$ Accepted: 30 Dec. 2021

\section{INTRODUCTION}

Video marketing is currently the best marketing strategy as people nowadays prefer watching videos rather than reading. A survey by Wyzowl (2020) showed that the average person spends 1.5 hours per day watching videos, and the number of organizations using video as a marketing tool also has increased from $61 \%$ to $85 \%$ since 2016 . TikTok as one of the social media platforms has rapidly developed and is predicted to beat the popularity of Instagram. TikTok has become the second most downloaded application in the world with 740 million times on Apple Store and Google Play Store in 2019 (Burhan, 2020). This creates an opportunity for marketers to promote their products via TikTok. For instance, Guess launched \#InMyDenim challenge on TikTok which got 10.5 million views, $14.3 \%$ engagement rate, more than 5,550 user participation videos and 12,000 new followers on Guess's official account during six-day campaign (TikTok for Business, 2020).

Despite the rapid development of digital and social media marketing, studies on advertising value's effect on purchase intention are still limited. Most studies only investigate how the advertising value shapes consumers' attitudes toward advertising (Arya \& Kerti, 2020; Brackett \& Carr, 2001; Ducoffe, 1996; Haghirian \& Madlberger, 2005; Liu et al., 2012; Murillo et al., 2016). In contrast, Morwitz (2012) argued that attitude alone is not adequate to predict sales. Marketers should at least measure purchase intentions as one of the main instruments for predicting sales. Hence, marketers should figure out advertising elements that can influence consumers' purchase intention.

Promoting through social media has several advantages which is expected to improve customers' purchase intentions. Dehghani et al. (2016) examined the effects of entertainment, informativeness, customization, and irritation on purchase intention on YouTube ads mediated by advertising value and brand awareness. Jain et al. (2018) investigated the effects of information, entertainment, and invasiveness on purchase intention in online advertisements through advertising value and attitude. Meanwhile, Martins et al. (2019) tested the mediating role of advertising value and flow experience in the relationships among irritability, informativeness, credibility, entertainment, incentives, and purchase intention of smartphone advertising.

The advantage of TikTok compared to other social media is an algorithm that can present relevant content according to user's interests and their frequently watched videos (Aruman, 2020). TikTok also allows marketers to interact with consumers in a more interesting and interactive way (Anugerah, 2020). In today's digital era, both personalization and the ability to build interactions are likely to increase the advertising value. However, there are relatively few studies that measure the influence of personalization and interactivity on 
consumers' purchase intention. Panniello et al. (2016) found that the relevance of an online recommendation has a positive influence on consumers' purchasing behavior, which is supported by Alalwan (2018), Dehghani et al. (2016), and Kim and Han (2014). Meanwhile, Abdullah et al. (2016) proposed a model of a relationship between perceived interactivity and a customer's intention to return to hotel websites. Several studies found that interactivity can predict purchase intention significantly (Alalwan, 2018; Yin et al., 2019).

Based on the discussion above, research on the effectiveness of advertising elements that influence consumers' purchase intentions on social media is relatively limited in numbers. There are also many variations in variables used to predict purchase intention. These include advertising value (Dehghani et al., 2016; Jain et al., 2018; Kim \& Han, 2014; Martins et al., 2019), brand awareness (Dehghani et al., 2016), attitude (Jain et al., 2018), flow experience (Kim \& Han, 2014; Martins et al., 2019), performance expectancy, and hedonic motivation (Alalwan, 2018). Although advertising value has been frequently studied, most of previous studies had not include the dimensions of personalization and interactivity as advertising value's factors in the context of social media advertising. Therefore, this study seeks to close the gap from previous research by investigating how entertainment, informativeness, credibility, irritation, personalization, and interactivity affecting purchase intention through advertising value and attitude toward advertising.

\section{LITERATURE REVIEW}

\section{Theoretical Framework}

An advertisement is a stimulus that is expected to attract the consumer's attention, generate favorable attitudes, and trigger purchase intention. This study uses a Stimulus-Organism-Response (SOR) approach as the underpinning theory and combines it with the Advertising Value Model refined by Brackett and Carr (2001). Based on the SOR theory proposed by Mehrabian and Russell (1974), an environment contains a stimulus (S) that can affect the organism $(\mathrm{O})$ to produce a response behavior $(\mathrm{R})$ to approach or avoid the stimulus. A stimulus is a factor that can affect an individual's internal condition. Organisms are internal processes and structures that act as mediators between a stimulus and an individual's final action, reaction, or response. A response is an individual's final outcome such as intention and behavior (Chang et al., 2011). Guided by the SOR model, this study investigates how the perceived advertising value stimulus together with personalization and interactivity of TikTok short video advertisements affects a customer's attitude toward advertising (organism) which ultimately affects purchase intention as a response.

An advertising value can be interpreted as a subjective evaluation of the relative value or usefulness of advertising for consumers (Ducoffe, 1996). Ducoffe (1996) stated that informativeness, entertainment, and irritation are antecedents of advertising value and attitude toward web advertising. Brackett and Carr (2001) then introduced credibility as the fourth antecedent of advertising value in the context of cyberspace advertising.

The ability to display ads that are relevant to the users and facilitate a high level of interactivity is the uniqueness of advertising on social media. These variables can boost ad's value, which is expected to improve customers' attitudes and purchase intentions. Research on the relationship between personalization and perceived advertising value shows inconsistent results (Fatima \& Abbas, 2016; Gaber et al., 2019; Kim \& Han, 2014; Wu \& Hsiao, 2017). Meanwhile, research regarding the effects of interactivity on advertising value has not focused on the context of social media ads. Thus, this study includes personalization and interactivity factors as additional antecedents that affect advertising value.

\section{Antecedents of Perceived Social Media Advertising Value}

Referring to Ducoffe's (1996), an advertisement may contain entertainment, informativeness, and irritation values. McQuail (1983, cited from Ducoffe, 1996, p. 23) defines entertainment as the ability to meet consumer needs for escape, diversion, aesthetic pleasure, or emotional pleasure. The ability of advertising to entertain is one of the main factors that can create an emotional connection between the brand and consumers (Wang \& Sun, 2010). According to Ducoffe (1996), consumers are more likely to give positive ratings for entertaining advertisements. If the content is less entertaining, the marketing effect will be much reduced (Xiao et al., 2019).

Martins et al. (2019) reported that the perceived entertainment of smartphone advertisements has a positive relationship with advertising value. A similar finding was found by Jain et al. (2018) on online video advertising. Arya and Kerti (2020) argued that millennial consumers view Instagram story ads as entertaining, which results in a positive perceived advertising value. A witty or funny image or video will have a positive impact on the advertising value for all audiences. This study tests the following hypothesis:

H1: Entertainment from short video advertisements has a positive influence on perceived advertising value.

Informativeness acts as an important predictor of an advertisement's value. Consumers will always look for informative advertisements to help them choose the best product that produces the greatest satisfaction (Ducoffe, 1996). Advertisements should consist of interesting and tailored information that meets their references to get a positive attitude (Reyck \& Degraeve, 2003), so that customers finally decide to make a purchase (Tsang et al., 2004).

Dehghani et al. (2016) and Murillo et al. (2016) revealed that consumers' perceived informativeness on advertising affects advertising value positively in social media platforms. Similarly, Arya and Kerti (2020) found that millennial users are interested in the informative ads displayed on their Instagram stories, which generate a positive effect on perceived advertising value. The relationship is shown through the following hypothesis:

H2: The informativeness of short video ads has a positive effect on the perceived advertising value.

According to Aaker et al. (1985), an advertisement may cause a disturbance, dissatisfaction, and even brief intolerance that refers to the irritation of advertisement value. The source of irritation comes from advertising strategies that are disruptive, offensive, or manipulative (Ducoffe, 1996) as well as an excessive amount of ads (Kim \& Sundar, 2010) and displaying information that is irrelevant or unwanted by customers (Lin \& Bautista, 2020). Irritation can make consumers feel displeased and react negatively to the advertisement (Aydogan et al., 2016).

Haghirian and Madlberger (2005) reported that the perceived irritation felt by consumers towards mobile ads decreased the advertising value. Tsang et al. (2004) also found that irritation negatively affects advertising value for consumers. Disastra et al. (2018) 
concluded that pop-up advertisements and irregular placement of advertisements on layouts can cause a high level of irritation to customers. Aydogan et al. (2016) suggested that non-irritating content in online advertising results in higher web advertising value. Based on these arguments, this study examines the following hypothesis:

H3: Irritation from short video ads has a negative effect on perceived advertising value.

Brackett and Carr (2001) integrated credibility into Ducoffe's (1996) model to explain the web advertising value. Advertisement credibility is the extent to which consumers perceive claims made about a brand in advertisements to be honest and trustworthy (MacKenzie \& Lutz, 1989). When customers believe that the message conveyed in the advertisement can be trusted, they will pay more attention to the advertisement (Kim \& Han, 2014). On the other hand, customers will avoid or not respond to an advertisement if they feel that the advertisement can not be trusted (Yang et al., 2013). This will negatively affect the customer's purchase intention for the product or service offered in the advertisement.

Credibility has the strongest positive impact on user ratings of advertising value (Arya \& Kerti, 2020). Martins et al. (2019) revealed that perceived credibility in mobile advertising has a positive relationship with perceived advertising value. Likewise, Murillo et al. (2016) found that credibility has a significant positive effect on advertising value on Twitter ads for Mexican millennials. Aydogan et al. (2016) argued that credibility in an online advertising resulted in a higher increase in web advertising value. This study examines the relationship between these variables through the following hypothesis:

H4: Credibility of short video ads has a positive effect on perceived advertising value.

The ability of the social media algorithm system allows users to only be exposed to ads that are personal to their needs and characteristics, so that they will like the ads. Advertising personalization refers to the delivery of advertising messages based on demographic factors, preferences, context, and content (Xu, 2016). In the context of mobile services, customers expect advertising content to be tailored to their interests (Robins, 2003). Ho and Kwok (2003) stated that personalization can reduce the number of irrelevant advertisements content sent to a customer. Marketers can collect information about consumers' preferences and create customized messages so that they can build relationships that are more personal with their customers (Feng et al., 2016). The personalization effect will create its own uniqueness, so that it can increase the value of social media ads (Kim \& Han, 2014; Segijn \& Ooijen, 2020).

Research on the relationship between personalization and perceived advertising value shows inconsistent results. Fatima and Abbas (2016) and Wu and Hsiao (2017) found that personalization plays an important role in determining advertising value. Different from that, Gaber et al. (2019) and Kim and Han (2014) concluded that personalization has an insignificant effect on advertising value. Therefore, it still needs further testing in a various context. This study tests the following hypothesis:

H5: Personalization of short video ads on TikTok has a positive effect on perceived advertising value.

Interactivity is a communication condition in which simultaneous and continuous exchange takes place, and this exchange carries the strength of social bonds (Rafaeli \& Sudweeks, 1997). Social media provides interactive two-way communication between the seller/brand and customers (Kaplan \& Haenlein, 2010). The ability of sender to convey information to the audience and the ability of receivers to give direct responses and share the information to others makes social media advertisements become more interactive. Social media can motivate customers to use text, images, videos, and links as interactive content that can be used as a strategy to monitor and promote new products or services to customers (Yaakop et al., 2013). Most customers who experience interactions with social media advertising will find the ad more useful and entertaining to follow, and they will be motivated to buy the product or service shown in the ad (Alalwan, 2018).

Interactivity can increase the value of advertising on social media (Logan et al., 2012; Shim et al., 2013). However, only few studies have looked at how interactivity affects advertising value, especially on social media advertising. Shim et al. (2013) found an indirect effect of interactivity on attitudes toward advertising through advertising value in the context of IPTV advertising. Likewise, Wu and Hsiao (2017) reported that interactivity increased advertising value for the context of mobile advertising. For this reason, the following hypothesis is proposed:

H6: Interactivity of short video ads has a positive effect on perceived advertising value.

\section{Consequences of the Perceived Social Media Advertising Value}

According to Ducoffe (1996), advertising value is defined as a subjective evaluation of the relative value or usefulness of advertising to consumers. This evaluation is understood as a cognitive assessment of the extent to which advertising gives consumers what they want (Ducoffe, 1996). In this study, perceived advertising value can be explained by the extent to which potential users believe that they will benefit from advertisements displayed on TikTok by evaluating several antecedent factors that have been discussed earlier.

Research by Liu et al. (2012) showed that consumers who have favorable attitudes toward mobile advertising are characterized by their high perception of the advertising value. Conversely, a negative attitude toward advertising might be triggered by advertising that lacks value (Ducoffe, 1996). A study by Murillo et al. (2016) on Mexican millennials found that advertising value had a positive effect on attitudes toward Twitter advertising. Kim and Han (2014) argued that the advertising value is the main predictor of purchase intention in the context of mobile advertising. Consumers have a favorable perception when they feel that the advertisements are a good source of receiving product information, credible, and enjoyable. The hypotheses to be tested are:

H7: The perceived advertising value of short video ads has a positive influence on attitudes toward advertising.

H8: The perceived advertising value of short video ads has a positive influence on purchase intention.

Attitude is an individual's positive or negative feelings toward the achievement of an objective (Fishbein \& Ajzen, 1975). Attitude is the consumer's liking, endorsement, or preference for product attributes, as a criterion used by consumers to make product purchase decisions $(\mathrm{Xu}, 2016)$. Behavioral intention is defined as a person's subjective possibility to take certain actions, while intention is a prominent factor in determining behavior (Davis, 1989). In this study, purchase intention is defined as the user's intention to buy a product in the future after watching a video that is shown on TikTok where the product is described or reviewed. 


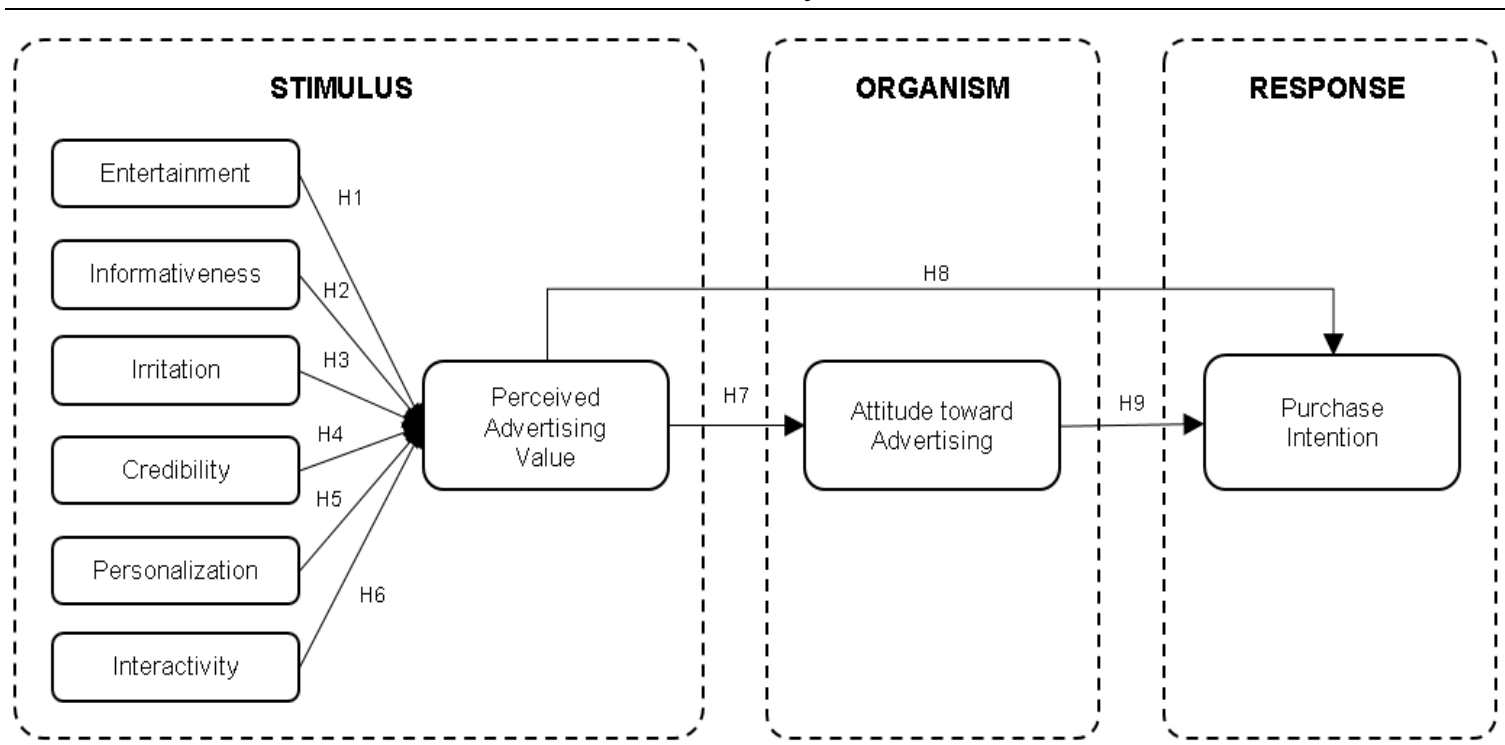

Figure 1. Research model

Zhao and Wang (2020) found that users who have positive attitudes on health-related short video ads are more likely to make product purchases. Jain et al. (2018) also found that attitude towards online video advertisements had a high influence on purchase intention among Indian youths. Xu's (2016) research on mobile advertising in China concluded that attitude is an important aspect in purchasing decisions that can be used to predict online purchase transactions. The relationship is stated as follows:

H9: Attitude toward advertising from short video ads has a positive influence on purchase intention.

The relationships between these variables are shown in Figure 1.

\section{METHODOLOGY}

\section{Research Design}

An online survey was conducted to obtain data from TikTok users in Indonesia who were active in the last three months and watched short video ad content at least three times a month. Links to participate in the survey were distributed via email, chat applications, and social media to cover a wide geographical area.

\section{Measures and Data Analysis}

This study investigated the effects of general short video ads on TikTok on customer purchase intentions rather than focusing on specific formats. The short video ads here include in-feed videos, brand takeovers, hashtag challenges, branded AR content, and custom influencer packages. The measurement items of each variable were sourced from various literature (Alalwan, 2018; Deraz, 2015; Ducoffe, 1996; Jain et al. 2018; Martins et al., 2019; Zhao \& Wang, 2020). Each latent variable was measured by four indicators, except for perceived advertising value that was only measured by three indicators. These items were measured using a 5-point Likert scale. The data was analyzed using PLS-SEM because this study extended the theory of advertising value, so that it aimed to maximize the predictive power of the social media advertising value in explaining purchase intention.
Table 1. Sample characteristics

\begin{tabular}{llcc}
\hline Demographic variable & & Freq. & \% \\
\hline \multirow{4}{*}{ Gender } & Male & 104 & 21.4 \\
\cline { 2 - 4 } & Female & 382 & 78.6 \\
\hline \multirow{4}{*}{ Age } & $<15$ years old & 2 & 0.4 \\
\cline { 2 - 4 } & $15-25$ years & 165 & 34.0 \\
\cline { 2 - 4 } & $26-35$ years old & 240 & 49.4 \\
\cline { 2 - 4 } Last education & 36-45 years old & 70 & 14.4 \\
\cline { 2 - 4 } & $>45$ years old & 9 & 1.9 \\
\hline \multirow{3}{*}{ Profession } & High school & 193 & 39.7 \\
\cline { 2 - 4 } & Undergraduate & 259 & 53.3 \\
\cline { 2 - 4 } & Postgraduate & 34 & 7.0 \\
\cline { 2 - 4 } & Student & 100 & 20.6 \\
\cline { 2 - 4 } & Army/policeman & 18 & 3.7 \\
\cline { 2 - 4 } & Public servant & 59 & 12.1 \\
\cline { 2 - 4 } & Private employee & 132 & 27.2 \\
\cline { 2 - 4 } & Entrepreneur & 93 & 19.1 \\
\cline { 2 - 4 } & Housewife & 48 & 9.9 \\
\cline { 2 - 4 } & Other & 36 & 7.4 \\
\hline
\end{tabular}

\section{RESULTS AND DISCUSSION}

The survey was carried out on January 2021 and was filled by 586 respondents. Of the total, only 486 respondents could meet the characteristics specified in this study. The majority of the respondents were women (78.6\%), aged 26-35 years (49.4\%), a diploma or bachelor's degree $(53.3 \%)$, and a private employee (27.2\%). The details of the characteristics of the respondents can be seen in Table 1.

\section{Measurement Model}

One irritation indicator (Irr1) was eliminated because its outer loading was less than 0.70 . The remaining indicators had an outer loading above 0.70 with the smallest value of 0.732 as shown in Table 2. The Fornell-Larcker criterion analysis showed that all square roots of AVE were greater than the correlation of the construct with other constructs (Table 3 ) that indicated the discriminant validity was met. 
Table 2. Construct reliability and convergent validity assessment

\begin{tabular}{|c|c|c|c|c|c|c|}
\hline Variables \& indicators & Mean & SD & OL & AVE & CR & $\mathbf{C A}$ \\
\hline Entertainment (Ent) & & & & & & \\
\hline Ent1 & 0.858 & 0.015 & 0.858 & \multirow{4}{*}{0.800} & \multirow{4}{*}{0.941} & \multirow{4}{*}{0.917} \\
\hline Ent2 & 0.904 & 0.013 & 0.905 & & & \\
\hline Ent3 & 0.921 & 0.009 & 0.921 & & & \\
\hline Ent4 & 0.893 & 0.011 & 0.893 & & & \\
\hline \multicolumn{7}{|l|}{ Informativeness (Inf) } \\
\hline Inf1 & 0.846 & 0.020 & 0.847 & \multirow{4}{*}{0.735} & \multirow{4}{*}{0.917} & \multirow{4}{*}{0.880} \\
\hline Inf2 & 0.865 & 0.016 & 0.865 & & & \\
\hline Inf3 & 0.852 & 0.018 & 0.852 & & & \\
\hline Inf4 & 0.864 & 0.018 & 0.864 & & & \\
\hline \multicolumn{7}{|l|}{ Irritation (Irr) } \\
\hline Irr2 & 0.885 & 0.039 & 0.886 & \multirow{3}{*}{0.668} & \multirow{3}{*}{0.857} & \multirow{3}{*}{0.774} \\
\hline Irr3 & 0.715 & 0.080 & 0.732 & & & \\
\hline Irr4 & 0.820 & 0.045 & 0.827 & & & \\
\hline Cre1 & 0.873 & 0.019 & 0.872 & \multirow{4}{*}{0.707} & \multirow{4}{*}{0.906} & \multirow{4}{*}{0.861} \\
\hline Cre2 & 0.877 & 0.016 & 0.877 & & & \\
\hline Cre3 & 0.762 & 0.028 & 0.762 & & & \\
\hline Cre4 & 0.846 & 0.025 & 0.847 & & & \\
\hline \multicolumn{7}{|l|}{ Personalization (Per) } \\
\hline Per1 & 0.852 & 0.016 & 0.852 & \multirow{4}{*}{0.737} & \multirow{4}{*}{0.918} & \multirow{4}{*}{0.881} \\
\hline Per2 & 0.836 & 0.028 & 0.837 & & & \\
\hline Per3 & 0.897 & 0.011 & 0.897 & & & \\
\hline Per4 & 0.847 & 0.016 & 0.847 & & & \\
\hline \multicolumn{7}{|l|}{ Interactivity (Int) } \\
\hline Int1 & 0.870 & 0.019 & 0.871 & \multirow{4}{*}{0.775} & \multirow{4}{*}{0.932} & \multirow{4}{*}{0.903} \\
\hline Int2 & 0.891 & 0.014 & 0.891 & & & \\
\hline Int3 & 0.891 & 0.013 & 0.892 & & & \\
\hline Int4 & 0.867 & 0.017 & 0.867 & & & \\
\hline Adv2 & 0.914 & 0.013 & 0.914 & 0.822 & 0.933 & 0.892 \\
\hline Adv3 & 0.910 & 0.014 & 0.909 & & & \\
\hline Attitude toward ads (A & & & & & & \\
\hline ATA1 & 0.858 & 0.022 & 0.859 & & & \\
\hline ATA2 & 0.852 & 0.018 & 0.852 & & & \\
\hline ATA3 & 0.862 & 0.015 & 0.861 & 0.703 & 0.904 & 0.858 \\
\hline ATA4 & 0.778 & 0.032 & 0.779 & & & \\
\hline Purchase intention (PI) & & & & & & \\
\hline PI1 & 0.897 & 0.017 & 0.896 & & & \\
\hline PI2 & 0.915 & 0.014 & 0.915 & & & \\
\hline $\mathrm{PI} 3$ & 0.905 & 0.012 & 0.905 & 0.799 & 0.941 & 0.916 \\
\hline PI4 & 0.859 & 0.015 & 0.859 & & & \\
\hline
\end{tabular}

OL: Outer loading; CR: Composite reliability; CA: Cronbach's alpha

Table 3. Results of discriminant validity

\begin{tabular}{|c|c|c|c|c|c|c|c|c|c|}
\hline & ATA & Cre & Ent & Inf & Int & Irr & Adv & Per & PI \\
\hline ATA & 0.838 & & & & & & & & \\
\hline Cre & 0.706 & 0.841 & & & & & & & \\
\hline Ent & 0.584 & 0.497 & 0.895 & & & & & & \\
\hline Inf & 0.609 & 0.582 & 0.641 & 0.857 & & & & & \\
\hline Int & 0.614 & 0.542 & 0.529 & 0.560 & 0.880 & & & & \\
\hline Irr & -0.281 & -0.257 & -0.245 & -0.276 & -0.229 & 0.818 & & & \\
\hline Adv & 0.765 & 0.644 & 0.615 & 0.573 & 0.653 & -0.240 & 0.907 & & \\
\hline Per & 0.734 & 0.684 & 0.642 & 0.606 & 0.621 & -0.235 & 0.737 & 0.859 & \\
\hline PI & 0.675 & 0.591 & 0.478 & 0.544 & 0.526 & -0.188 & 0.645 & 0.674 & 0.894 \\
\hline
\end{tabular}

\section{Structural Model}

The testing of each relationship between the latent variables was carried out using the output bootstrapping to the sample to minimize the problem of abnormal research data. The results of the hypothesis testing (bootstrapping into 5,000 samples) are presented in Figure 2 and Table 4.

The six elements of social media advertising value explained the perceived advertising value by 64.1 percent. Among variables that make 


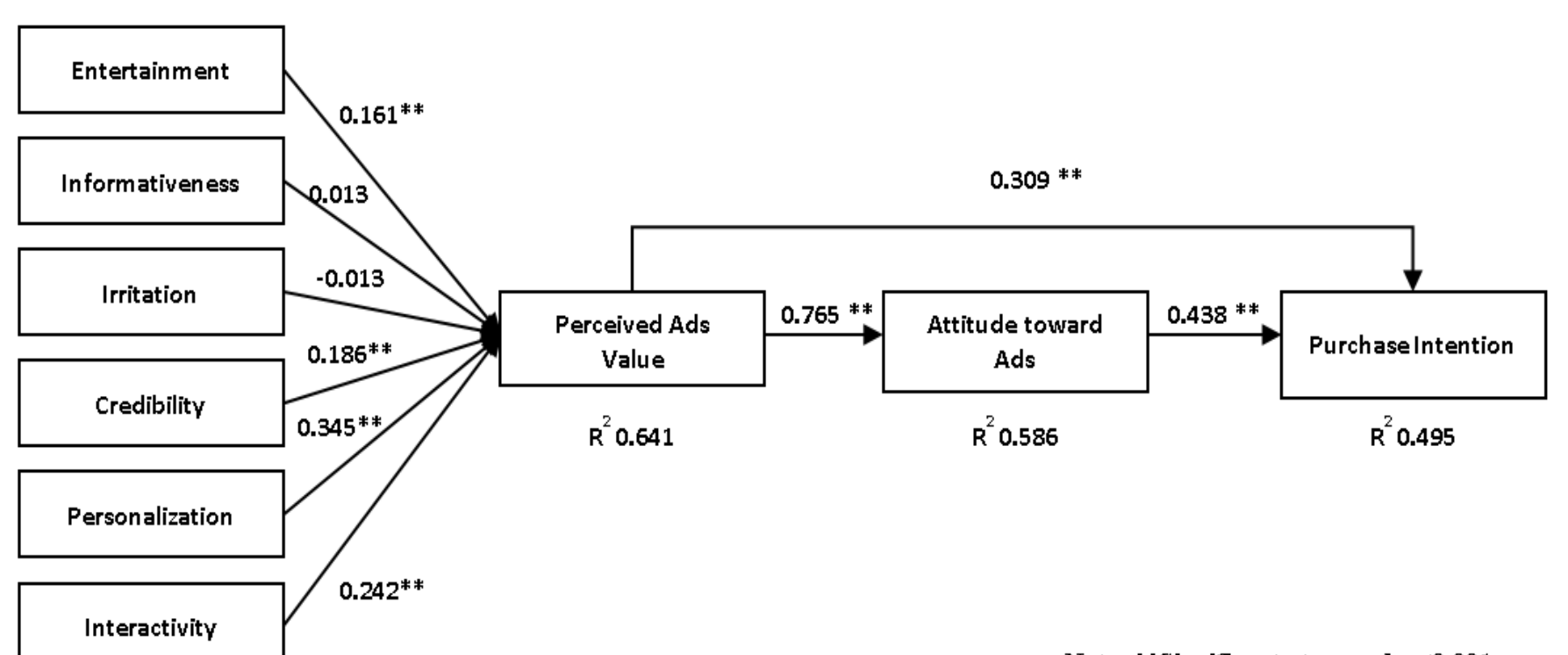

Note: * Significant at a p-value $\leq 0.001$

Figure 2. Path diagram

Table 4. Path coefficient test results

\begin{tabular}{lcccc}
\hline Path & PC & SE & t-value & p-value \\
\hline H1: Ent $\rightarrow$ Adv & 0.161 & 0.050 & 3.203 & 0.001 \\
\hline H2: Inf $\rightarrow$ Adv & 0.013 & 0.057 & 0.234 & 0.408 \\
\hline H3: Irr $\rightarrow$ Adv & -0.013 & 0.027 & 0.471 & 0.319 \\
\hline H4: Cre $\rightarrow$ Adv & 0.186 & 0.046 & 4.052 & 0.000 \\
\hline H5: Per $\rightarrow$ Adv & 0.345 & 0.056 & 6.180 & 0.000 \\
\hline H6: Int $\rightarrow$ Adv & 0.242 & 0.050 & 4.888 & 0.000 \\
\hline H7: Adv $\rightarrow$ ATA & 0.765 & 0.020 & 38.119 & 0.000 \\
\hline H8: Adv $\rightarrow$ PI & 0.309 & 0.054 & 5.760 & 0.000 \\
\hline H9: ATA $\rightarrow$ PI & 0.438 & 0.053 & 8.237 & 0.000 \\
\hline Coefficient of determination, $\mathbf{R}^{\mathbf{2}}$ & & & \\
\hline Adv & 0.641 & & & \\
\hline ATA & 0.586 & & & \\
\hline PI & 0.495 & & & \\
\hline PC: Path coeficin & & & & \\
\hline
\end{tabular}

PC: Path coefficient

up the perceived advertising value, personalization had the strongest effect $(\beta=0.345, p<0.01)$, followed by interactivity $(\beta=0.242, p<0.01)$, credibility $(\beta=0.186, p<0.01)$, and entertainment $(\beta=0.161, p<0.01)$. Thus, hypotheses H1, H4, H5, and H6 were supported. Whilst $\mathbf{H 2}$ and H3 were rejected since informativeness $(\beta=0.013, p=0.408)$ and irritation $(\beta=-0.013, \mathrm{p}=0.319)$ had no significant effect.

The perceived advertising value positively influenced attitude toward the advertising $(\beta=0.765, \mathrm{p}<0.01)$ that supported $\mathbf{H} 7$. About 58.6 percent of the variability of attitude towards the advertising could be explained by the perceived advertising value. Both perceived advertising value and attitude toward advertising explained the variability of purchase intention by 49.5 percent. The effect of perceived advertising value on purchase intention $(\beta=0.309, \mathrm{p}<0.01)$ was lower than attitude toward the advertising effect on purchase intention $(\beta=0.438, p<0.01)$. As both relationships were significant, then $\mathbf{H 8}$ and H9 were supported.

\section{DISCUSSION}

The majority of the respondents were Millennial and Gen-Z which very familiar with the development of digital technology and use social media to find product information (Loeb, 2020). They liked music, movies, and gaming as their top five interests (Dooley, 2019) and valued relevance, experiences, innovation, trust, transparency, and simplicity (AUTUMNFAIR, 2019; Woo, 2018). All of these characteristics are reflected in the findings of this study.

We found that personalization and interactivity play the most dominant role in the formation of advertising value, followed by credibility and entertainment. Millennial and Gen-Z prefer social media advertisements that can meet their preferences and relevant to their needs. The ability of social media algorithms to filter ads according to user preferences and characteristics make it possible to deliver more individualized ads (Robins, 2003; Unal et al. 2011). This ability is proven to play the biggest role in shaping the perceived advertising value which is in line with Segijn and Ooijen (2020). These findings are also consistent with the results of research by Fatima and Abbas (2016) and $\mathrm{Wu}$ and Hsiao (2017). Thus, personalization becomes a main consideration factor in designing TikTok video ads.

Interaction with consumers also supports the success of an advertisement. TikTok allows customers to actively participate in creating their own videos (user-generated content). TikTok also provides a polling survey feature that can further increase interactivity between brands and consumers. It makes customers feel that the seller/brand wants to listen to their opinions. The seller/brand can later customize the advertising content based on customers' feedbacks to increase their perceived advertising value. Similar findings were reported by Logan et al. (2012), Shim et al. (2013), and Wu and Hsiao (2017), where interactivity can increase the social media advertising value. Most customers will find an advertisement more useful and entertaining to follow if they can interact with it, and in the end they will be motivated to buy the product or service that is offered (Alalwan, 2018).

This study found a positive relationship between entertainment and the formation of perceived advertising value because the respondents felt entertained and enjoyed watching TikTok video ads. The content displayed on TikTok ads is generally funny or involves dancing, acting, and lip-syncing which meet the interests of Millennials and Gen-Z. This result is in line with the findings of Ducoffe (1996) 
that entertainment has a positive effect on advertising value. Likewise, Jain et al. (2018) discovered that entertainment has a high influence on advertisement value and suggests that marketers can increase the entertainment element when designing their marketing videos to get more viewers. Murillo et al. (2016) stated that entertainment is one of the strongest predictors that significantly affects the perception of advertising value on Twitter and writing witty, funny, or entertaining promotional tweets positively affects user ratings of advertising.

The element of credibility also has a positive influence on the perceived advertising value. The respondents felt that TikTok video ads was trustworthy and came from a credible source. It supports Haghirian and Madlberger (2005) as well as Martins et al. (2019) in different contexts. Many brands today use influencers to promote their products on TikTok. Referring to Saima and Khan (2020), the influencer's credibility depends on his/her trustworthiness, information quality, and entertainment value of the content. Millennials and Gen- $Z$ tend to highly trust influencers and 1.3 times more likely to buy products recommended by them than celebrities or television ads (Brooks, 2019). Customers also can view product review videos by influencers and other TikTok users. As many as $78 \%$ of Gen- $Z$ tend to read other customer reviews of the products offered before deciding to buy the product (Brooks, 2019). When customers believe that the message conveyed in the advertisement can be trusted, they will pay more attention to the advertisement (Kim \& Han, 2014).

Meanwhile, the informativeness element of TikTok video ads does not significantly affect the perceived advertising value. This finding is contrary to most research, which concluded that informativeness has a significant influence on advertising value (Arya \& Kerti, 2020; Dehghani et al., 2016; Murillo et al. 2016). TikTok ads are generally short, only between 3 to 60 seconds. Some ads provide a link at the end of the short video, which can direct customers to the brand's page for more detailed information. Although most respondents felt that TikTok video ads were very entertaining, it might be the reason that they eventually became distracted by the entertainment elements itself and did not pay full attention to the product information being conveyed. Chowdhury et al. (2006) found that respondents in Bangladesh felt that advertising on mobile advertising was less informative since most users may not fully read and remember the information displayed in the ads. Therefore, advertising videos on TikTok should only contain important points related to the product, and it would be even better if the information could be conveyed entirely through the video in order to immediately attract customers' interest.

The irritation element of short video ads on TikTok also has an insignificant effect on the perceived advertising value. Based on the results of this study, the respondents felt that the advertisements displayed on TikTok met their interests, interactive, credible, and entertaining, so that the irritation element becomes insignificant. This finding is in line with Kim and Han (2014), where personalization, credibility, and entertainment can reduce irritation levels that can increase the advertising value. Customers tend to have a good perception of advertising if the advertisement is credible, fun, and brings economic benefits, even though at the same time they feel disturbed. Haghirian and Madlberger (2005) argued that negative perceptions of irritation can be minimized if the message conveyed in the advertisement is relevant and provides value for the recipient.
Finally, this study found that the perceived advertising value has a significant positive effect on attitudes toward advertising and both perceived advertising value and attitude toward advertising affect customers' purchase intention in TikTok ads. We also found that the influence of attitude toward advertising on purchase intention is stronger than the perceived advertising value. The respondents felt that the short video ads on TikTok are personalized, interactive, entertaining, and credible for them, which play an important role in forming a high perception of advertising value that will stimulate their positive attitudes toward the ads and later produce their intention to make a product purchase. Jain et al. (2018) found that attitude towards online video advertisements had a high influence on purchase intention among Indian Youth. Xu (2016) concluded that attitude towards mobile advertising in China was the key element in predicting online purchase transactions as attitude is significantly correlated with intention.

\section{IMPLICATIONS \& SUGGESTIONS}

\section{Theoretical Implications}

The theory of advertising value originally developed by Ducoffe (1996) and later refined by Brackett and Carr (2001) has been widely discussed in website and social media advertising research. However, only a few studies have taken into account personalization and interactivity as unique factors that can boost the value of an advertisement (Alalwan, 2018; Fatima \& Abbas, 2016; Wu \& Hsiao, 2017; Yaakop et al., 2013). Through this research, we confirm that personalization and interactivity play the most dominant role in the formation of advertising value. The presence of these two elements, along with the entertainment element, is able to minimize the effect of irritation and informativeness to an insignificant level. A strong advertising value will make ads more favorable for consumer and they are more likely to purchase the product or service.

\section{Managerial Implications}

Before utilizing TikTok as promotional media, marketers need to understand the factors that can influence customers' purchase intentions in order to formulate effective strategies to increase sales. The key is to implement a customer-centric strategy by understanding their customers' needs and behavior.

Based on the results of this study, personalization and interactivity should be considered when creating advertising content on TikTok. Personalization can minimize the irritation felt by TikTok users while interactive advertising allows marketers to interact directly with users. By doing so, marketers can establish an emotional connection with users to create a more personal relationship between the brand and its customers. Other factors which should also be considered are credibility and entertainment. Marketers should pay attention to factors that can increase brand credibility and build entertaining content in which advertising messages are immersed. However, they should balance between entertainment and informativeness factors so it does not distract the customers' focus.

The four elements above play an important role in forming considerably high advertising value attitudes which foster positive attitudes and stimulate purchase intention. Thus, our research can be an insight for marketers to focus on efforts in designing effective advertising content by considering personalization, interactivity, credibility, and entertainment factors. 
Limitations and Suggestions for Further Research

This study found the six elements of video advertising on TikTok accounted for $64.1 \%$ of variance in perceived advertising value, and advertising value can only explain $58.6 \%$ of variance in attitude toward advertising. Hence, there is still a gap for future research to improve the predictive ability of these elements. Further research can enrich the research model by adding other variables that have not been accommodated in this study, such as trialability and incentive effects on the advertising value and the advertising value impact on brand awareness which in turn can also affect purchase intention.

This study also examined the effects of short video ads on TikTok in general rather than focusing on specific ads format and specific age groups. Future research can focus the subjects on Gen-Z, since based on a survey conducted by Globalwebindex (2019), as quoted by Mohsin (2021), $41 \%$ of TikTok users are aged between 16-24 years and this number will continue to grow. Research can also focus on more specific TikTok ads format such as hashtag challenges and branded AR content where research on this subject is still relatively rare.

Author contributions: All authors were involved in concept, design, collection of data, interpretation, writing, and critically revising the article. All authors approve final version of the article.

Funding: The authors received no financial support for the research and/or authorship of this article.

Declaration of interest: Authors declare no competing interest.

Data availability: Data generated or analysed during this study are available from the authors on request.

\section{REFERENCES}

Aaker, D. A., \& Bruzzone, D. E. (1985). Causes of irritation in advertising. Journal of Marketing, 49(2), 47-57. https://doi.org/ 10.1177/002224298504900204

Abdullah, D., Jayaraman, K., \& Kamal, S. B. (2016). A conceptual model of interactive hotel website: The role of perceived website interactivity and customer perceived value toward website revisit intention. Procedia Economics and Finance, 37, 170-175. https://doi.org/10.1016/s2212-5671(16)30109-5

Alalwan, A. A. (2018). Investigating the impact of social media advertising features on customer purchase intention. International Journal of Information Management, 42, 65-77. https://doi.org/ 10.1016/j.ijinfomgt.2018.06.001

Anugerah, Y. (2020). TikTok: Social media marketing platform paling hot \& trending 2021. Meson. https://meson-digital.com/blog /social-media/tiktok-marketing-tips/

Aruman, E. (2020). Yang membedakan TikTok dari media sosial lain [What sets TikTok apart from other social media]. Marcomm. https://mix.co.id/marcomm/news-trend/yang-membedakan-tiktok-dari-media-sosial-lain

Arya, M. P., \& Kerti, Y. N. N. (2020). Advertising value of Instagram stories and the effect on millennial's attitude. Russian Journal of Agricultural and Socio-Economic Sciences, 3(99), 29-39. https://doi.org/10.18551/rjoas.2020-03.04

AUTUMNFAIR. (2019). Generation Z characteristics and buying behaviour. https://www.autumnfair.com/news/generation-zcharacteristics-and-buying-behaviour
Aydogan, S., Aysuna, C., \& Aktan, M. (2016). Web advertising value and students' attitude towards web advertising. European Journal of Business and Management, 8(9), 86-97.

Brackett, L. K., \& Carr, B. N. (2001). Cyberspace advertising vs. other media: Consumer vs. mature student attitudes. Journal of Advertising Research, 41(5), 23-32. https://doi.org/10.2501/jar-41-5-23-32

Brooks, A. (2019). How brands can connect with Gen Z through social media marketing. Social Media Today. https://www.socialmediatoday.com/news/how-brands-canconnect-with-gen-z-through-social-media-marketing/552161/

Burhan, F. A. (2020). Punya 625 juta pengguna aktif, TikTok bisa lebih besar dari Instagram [With 625 million active users, TikTok could be bigger than Instagram]. Katadata. https://katadata.co.id/ happyfajrian/digital/5e9a498fee4f1/punya-625-juta-penggunaaktif-tiktok-bisa-lebih-besar-dari-instagram

Chang, H., Eckman, M., \& Yan, R. (2011). Application of the stimulusorganism-response model to the retail environment: The role of hedonic motivation in impulse buying behavior. The International Review of Retail, Distribution and Consumer Research, 21(3), 233-249. https://doi.org/10.1080/09593969.2011.578798

Chowdhury, H. K., Parvin, N., Weitenberner, C., \& Becker, M. (2006). Consumer attitude toward mobile advertising in an emerging market: An empirical study. International Journal of Mobile Marketing, 1(2), 33-41.

Davis, F. D. (1989). Perceived usefulness, perceived ease of use, and user acceptance of information technology. MIS Quarterly, 13(3), 319339. https://doi.org/10.2307/249008

Dehghani, M., Niaki, M. K., Ramezani, I., \& Sali, R. (2016). Evaluating the influence of YouTube advertising for attraction of young customers. Computers in Human Behavior, 59, 165-172. https://doi.org/10.1016/j.chb.2016.01.037

Deraz, H. (2015). Factors predicting consumers' assessment of advertisements on social networking sites. International Journal of Digital Information and Wireless Communications, 5(2), 111-123. https://doi.org/10.17781/p001671

Disastra, G. M., Hanifa, F. H., Wulandari, A., \& Sastika, W. (2019). The influence of advertising value on advertising attitude and its impact on purchase intention. Advances in Social Science, Education, and Humanities Research, 307, 426-432. https://doi.org/10.2991/sores18.2019 .98

Dooley, J. (2019). Gen Z consumers: Nearly $100 \%$ own a smartphone and spend over 4 hours per day online. ClickZ. https://www.clickz. com/gen-z-consumers-nearly-100-percent-own-a-smartphoneand-spend-over-4-hours-per-day-online/246757/

Ducoffe, R. H. (1996). Advertising value and advertising on the web. Journal of Advertising Research, 36(5), 21-35.

Fatima, T., \& Abbas, T. (2016). Impact of advertising beliefs and personalization on attitude towards advertising; Mediating role of advertising value. International Journal of Business Management and Commerce, 1(2), 10-19.

Feng, X., Fu, S., \& Qin, J. (2016). Determinants of consumers' attitudes toward mobile advertising: The mediating roles of intrinsic and extrinsic motivations. Computers in Human Behavior, 63, 334-341. https://doi.org/10.1016/j.chb.2016.05.024 
Fishbein, M., \& Ajzen, I. (1975). Belief, attitude, intention, and behavior: An introduction to theory and research. Addison-Wesley.

Gaber, H. R., Wright, L. T., \& Kooli, K. (2019). Consumer attitudes towards Instagram advertisements in Egypt: The role of the perceived advertising value and personalization. Cogent Business $\mathcal{E}$ Management, 6(1), 1618431. https://doi.org/10.1080/23311975. 2019.1618431

Haghirian, P., \& Madlberger, M. (2005). Consumer attitude toward advertising via mobile devices - An empirical investigation among Austrian users. European Conference on Information Systems 2005 Proceedings, 44.

Ho, S. Y., \& Kwok, S. H. (2002). The attraction of personalized service for users in mobile commerce. ACM SIGecom Exchanges, 3(4), 10-18. https://doi.org/10.1145/844351.844354

Jain, G., Rakesh, S., \& Chaturvedi, K. R. (2018). Online video advertisements' effect on purchase intention. International Journal of E-Business Research, 14(2), 87-101. https://doi.org/10.4018/ijebr. 2018040106

Kaplan, A. M., \& Haenlein, M. (2010). Users of the world, unite! The challenges and opportunities of social media. Business Horizons, 53(1), 59-68. https://doi.org/10.1016/j.bushor.2009.09.003

Kim, Y. J., \& Han, J. (2014). Why smartphone advertising attracts customers: A model of web advertising, flow, and personalization. Computers in Human Behavior, 33, 256-269. https://doi.org/10.1016/ j.chb.2014.01.015

Lin, T. T., \& Bautista, J. R. (2018). Content-related factors influence perceived value of location-based mobile advertising. Journal of Computer Information Systems, 60(2), 184-193. https://doi.org/ 10.1080/08874417.2018.1432995

Liu, C., Sinkovics, R., Pezderka, N., \& Haghirian, P. (2012). Determinants of consumer perceptions toward mobile advertisingA comparison between Japan and Austria. Journal of Interactive Marketing, 26(1), 21-32. https://doi.org/10.1016/j.intmar.2011.07. 002

Loeb, W. (2020). Social media plays a big role in how millennials shop but so do stores. Forbes. https://www.forbes.com/sites/walterloeb/ 2020/01/21/why-millennials-shop-on-social-media-but-also-liketo-shop-in-stores/?sh=125488b9350c

Logan, K., Bright, L. F., \& Gangadharbatla, H. (2012). Facebook versus television: Advertising value perceptions among females. Journal of Research in Interactive Marketing, 6(3), 164-179. https://doi.org/ 10.1108/17505931211274651

MacKenzie, S. B., \& Lutz, R. J. (1989). An empirical examination of the structural antecedents of attitude toward the ad in an advertising pretesting context. Journal of Marketing, 53(2), 48-65. https://doi.org/10.2307/1251413

Martins, J., Costa, C., Oliveira, T., Gonçalves, R., \& Branco, F. (2019). How smartphone advertising influences consumers' purchase intention. Journal of Business Research, 94, 378-387. https://doi.org/ 10.1016/j.jbusres.2017.12.047

Mehrabian, A., \& Russell, J. A. (1974). An approach to environmental psychology. MIT Press.

Mohsin, M. (2021). 10 TikTok statistics that you need to know in 2021 Oberlo. https://id.oberlo.com/blog/tiktok-statistics
Morwitz, V. (2012). Consumers' purchase intentions and their behavior. Foundations and Trends in Marketing, 7(3), 181-230. https://doi.org/10.1561/1700000036

Murillo, E., Merino, M., \& Núñez, A. (2016). The advertising value of Twitter ads: A study among Mexican millennials. Review of Business Management, 18(61), 436-456. https://doi.org/10.7819/rbgn. v18i61.2471

Panniello, U., Hill, S., \& Gorgoglione, M. (2016). The impact of profit incentives on the relevance of online recommendations. Electronic Commerce Research and Applications, 20, 87-104. https://doi.org/ 10.1016/j.elerap.2016.10.003

Rafaeli, S., \& Sudweeks, F. (1997). Networked interactivity. Journal of Computer-Mediated Communication, 2(4), JCMC243. https://doi.org/ 10.1111/j.1083-6101.1997.tb00201.x

Reyck, B. D., \& Degraeve, Z. (2003). Broadcast scheduling for mobile advertising. Operations Research, 51(4), 509-517. https://doi.org/ 10.1287/opre.51.4.509.16104

Robins, F. (2003). The marketing of 3G. Marketing Intelligence and Planning, 21(6), 370-378. https://doi.org/10.1108/02634500310499 239

Saima, \& Khan, M. A. (2020). Effect of social media influencer marketing on consumers' purchase intention and the mediating role of credibility. Journal of Promotion Management, 27(4), 503-523. https://doi.org/10.1080/10496491.2020.1851847

Segijn, C. M., \& van Ooijen, I. (2020). Differences in consumer knowledge and perceptions of personalized advertising: Comparing online behavioural advertising and synced advertising. Journal of Marketing Communications, 1-20. https://doi.org/10.1080/135272 66.2020 .1857297

Shim, S. W., Lee, C., \& Kim, D. (2013). The antecedents of attitude toward IPTV advertising: The role of interactivity and advertising value. The Korean Journal of Advertising, 2(1), 123-161. https://doi.org/10.14377/japr.2013.3.30.123

TikTok for Business. (2020). Guess: Lifting brand engagement and brand affinity among the young generation in the U.S. TikTok for Business. https://www.tiktok.com/business/id/inspiration/7

Tsang, M. M., Ho, S., \& Liang, T. (2004). Consumer attitudes toward mobile advertising: An empirical study. International Journal of Electronic Commerce, 8(3), 65-78. https://doi.org/10.1080/10864415 .2004 .11044301

Unal, S., Ercis, A., \& Keser, E. (2011). Attitudes towards mobile advertising - A research to determine the differences between the attitudes of youth and adults. Procedia - Social and Behavioral Sciences, 24, 361-377. https://doi.org/10.1016/j.sbspro.2011.09.067

Wang, Y., \& Sun, S. (2010). Assessing beliefs, attitudes, and behavioral responses toward online advertising in three countries. International Business Review, 19(4), 333-344. https://doi.org/10.1016/j.ibusrev. 2010.01.004

Woo, A. (2018). Understanding the research on millennial shopping behaviors. Forbes. https://www.forbes.com/sites/forbesagency council/2018/06/04/understanding-the-research-on-millennialshopping-behaviors/?sh=128fcae $15 \mathrm{f} 7 \mathrm{a}$ 
Wu, I. L., \& Hsiao, W. H. (2017). Involvement, content, and interactivity drivers for consumer loyalty in mobile advertising: The mediating role of advertising value. International Journal of Mobile Communications, 15(6), 577-603. https://doi.org/10.1504/ ijmc. 2017.086878

Wyzowl. (2020). Video marketing statistics 2020. https://www. wyzowl.com/state-of-video-marketing-2020-report/

Xiao, Y., Wang, L., \& Wang, P. (2019). Research on the influence of content features of short video marketing on consumer purchase intentions. In W. Striełkowski (Ed.), Advances in social science, education and humanities research (pp. 415-422). https://doi.org/ 10.2991/mmetss-19.2019.82

$\mathrm{Xu}, \mathrm{D} . \mathrm{J}$. (2016). The influence of personalization in affecting consumer attitudes toward mobile advertising in China. Journal of Computer Information Systems, 47(2), 9-19.
Yaakop, A., Anuar, M. M., \& Omar, K. (2013). Like it or not: Issue of credibility in Facebook advertising. Asian Social Science, 9(3), 154163. https://doi.org/10.5539/ass.v9n3p154

Yang, B., Kim, Y., \& Yoo, C. (2013). The integrated mobile advertising model: The effects of technology- and emotion-based evaluations. Journal of Business Research, 66(9), 1345-1352. https://doi.org/ 10.1016/j.jbusres.2012.02.035

Yin, X., Wang, H., Xia, Q., \& Gu, Q. (2019). How social interaction affects purchase intention in social commerce: A cultural perspective. Sustainability, 11(8), 2423. https://doi.org/10.3390/ su11082423

Zhao, J., \& Wang, J. (2020). Health advertising on short-video social media: A study on user attitudes based on the extended technology acceptance model. International Journal of Environmental Research and Public Health, 17(5), 1501. https://doi.org/10.3390/ijerph17051501 